\title{
Marichromatium fluminis sp. nov., a slightly alkaliphilic, phototrophic gammaproteobacterium isolated from river sediment
}

\author{
Correspondence \\ Ch. Sasikala \\ sasi449@yahoo.ie
}

\author{
K. Sucharita, ${ }^{1}$ E. Shiva Kumar, ${ }^{1}$ Ch. Sasikala, ${ }^{1}$ B. B. Panda, ${ }^{2}$ S. Takaichi ${ }^{3}$ \\ and Ch. V. Ramana ${ }^{4}$
}

${ }^{1}$ Bacterial Discovery Laboratory, Centre for Environment, Institute of Science and Technology, J. N. T. University, Kukatpally, Hyderabad 500 085, India

${ }^{2}$ Department of Botany, Bharampur University, Bharampur, Orissa, India

${ }^{3}$ Department of Biology, Nippon Medical School, Kosugi-cho, Nakahara, Kawasaki 211-0063, Japan

${ }^{4}$ Department of Plant Sciences, School of Life Sciences, University of Hyderabad, PO Central University, Hyderabad 500 046, India

\begin{abstract}
An anoxygenic, phototrophic gammaproteobacterium designated strain $\mathrm{JA} 418^{\top}$ was isolated from a sediment sample collected from the Baitarani River, Orissa, India. The bacterium was a Gramnegative, motile rod with a single polar flagellum. Bacteriochlorophyll $a$ and rhodopin were the major photosynthetic pigments. The organism grew best at slightly alkaline $\mathrm{pH}(8-8.5)$ and lacked chemotrophic growth. The major fatty acids were $\mathrm{C}_{16: 0}, \mathrm{C}_{16: 1} \omega 7 c / \mathrm{C}_{16: 1} \omega 6 c$ and $\mathrm{C}_{18: 1} \omega 7 c$. $\mathrm{A}$ phylogenetic tree based on $16 \mathrm{~S}$ rRNA gene sequence analysis showed that strain JA418 ${ }^{\top}$ clusters with species of the genus Marichromatium belonging to the class Gammaproteobacteria. The highest $16 \mathrm{~S}$ rRNA gene sequence similarities of strain $\mathrm{JA} 418^{\top}$ were found with the type strains of Marichromatium gracile (95.9\%), Marichromatium indicum (95.6\%), Marichromatium purpuratum (95.5\%) and Marichromatium bheemlicum (95.6\%). The DNA base composition of strain $\mathrm{JA} 418^{\top}$ was $71.4 \mathrm{~mol} \% \mathrm{G}+\mathrm{C}$ (by HPLC). Based on the $16 \mathrm{~S}$ rRNA gene sequence analysis and physiological and chemotaxonomic characteristics, strain $\mathrm{JA} 418^{\top}$ is sufficiently different from other Marichromatium species to merit the description of a novel species, Marichromatium fluminis sp. nov., to accommodate it. The type strain is JA418 ${ }^{\top}$ (=KCTC $5717^{\top}$ $=$ NBRC $105221^{\top}$ ).
\end{abstract}

The genus Marichromatium comprises four species with validly published names, Marichromatium gracile, Mch. purpuratum, Mch. indicum (Arunasri et al., 2005) and Mch. bheemlicum (Anil Kumar et al., 2007). Mch. gracile biotype thermosulfidiphilum is a newly described biotype of the species Mch. gracile (Serrano et al., 2009). In this paper, we propose a novel species of the genus Marichromatium based on a strain that grows optimally at slightly alkaline $\mathrm{pH}$; alkaliphilic growth is not widespread among the phototrophic members of the family Chromatiaceae (Imhoff, 2005).

Strain JA418 ${ }^{\mathrm{T}}$ was isolated from phototrophic [anaerobic, light $\left.\left(30 \mu \mathrm{E} \mathrm{m}^{-2} \mathrm{~s}^{-1}\right)\right]$ enrichments of a sediment sample

The GenBank/EMBL/DDBJ accession number for the $16 \mathrm{~S}$ rRNA gene sequence of strain $\mathrm{JA} 418^{\top}$ is FM210274.

Details of the effects of $\mathrm{NaCl}$ concentration and $\mathrm{pH}$ on growth and absorption spectra from cells of $\mathrm{JA} 418^{\top}$ are available as supplementary material with the online version of this paper. collected from the Baitarani River in Kalibanj forest, Orissa, India, by using the medium ( $\mathrm{pH}$ 6.8) of Pfennig (Pfennig \& Trüper, 1992) supplemented with sodium chloride $(1 \% \mathrm{w} / \mathrm{v})$ and with pyruvate $(0.3 \% \mathrm{w} / \mathrm{v})$ as carbon source/electron donor and ammonium chloride $(0.12 \%)$ as nitrogen source. Samples were collected on 31 May 2008 and the GPS position of the sample collection site is $20^{\circ} 47.284^{\prime} \mathrm{N} 086^{\circ} 52.646^{\prime} \mathrm{E}$. The sample that yielded strain $\mathrm{JA} 418^{\mathrm{T}}$ had a $\mathrm{pH}$ of 6.8 (the $\mathrm{pH}$ of the lagoon is known to vary temporally between 6.5 and 9), a salinity of $2.5 \% \mathrm{NaCl}$ and a temperature of $30{ }^{\circ} \mathrm{C}$. Purification was achieved by repeated streaking on agar slants $(25 \times 150 \mathrm{~mm}$ test tubes sealed with butyl rubber stoppers and the gas phase replaced with argon). Purified cultures were grown in completely filled screw-capped test tubes $(10 \times 100 \mathrm{~mm})$ for photoheterotrophic growth. For routine culturing and for physiological tests, strain $\mathrm{JA} 418^{\mathrm{T}}$ was grown at $\mathrm{pH} 8,30{ }^{\circ} \mathrm{C}$ and at a light intensity of $30 \mu \mathrm{E} \mathrm{m}{ }^{-2}$ $\mathrm{s}^{-1}$. Growth experiments at $\mathrm{pH}$ 6-12 were performed 
(protocol of Aino et al., 2008) using the basal medium of Pfennig (Pfennig \& Trüper, 1992) buffered with $100 \mathrm{mM}$ $\mathrm{NaH}_{2} \mathrm{PO}_{4} / \mathrm{Na}_{2} \mathrm{HPO}_{4} \quad(\mathrm{pH} 6-7.5), \quad 100 \mathrm{mM} \quad \mathrm{NaHCO}_{3} /$ $\mathrm{Na}_{2} \mathrm{CO}_{3}(\mathrm{pH} 8-9.5)$ or $100 \mathrm{mM} \mathrm{Na} \mathrm{CO}_{3} / \mathrm{NaOH}(\mathrm{pH} 10-$ 12). Morphological properties (cell shape, cell division, cell size, flagella) were observed by light microscopy (Olympus $\mathrm{BH}-2)$. To study the ultrastructure of the flagella, cells were stained with $1 \%$ phosphotungstic acid; ultrathin sections were viewed through a transmission electron microscope (H-7500; Hitachi) to examine intracytoplasmic structures such as the internal membrane system. In vivo absorption spectra were measured with a Spectronic Genesys 2 spectrophotometer using a sucrose solution for cell suspension (Pfennig \& Trüper, 1992). Carotenoid composition was analysed by using HPLC (Takaichi \& Shimada, 1992). The utilization of different carbon substrates and electron donors $(0.3 \% \mathrm{w} / \mathrm{v}$ or $\mathrm{v} / \mathrm{v}$, unless otherwise mentioned) was tested in the medium of Pfennig (Pfennig \& Trüper, 1992) containing $1 \mathrm{mM} \mathrm{Na}_{2} \mathrm{~S} .9 \mathrm{H}_{2} \mathrm{O}$.

Ammonium chloride was replaced with different nitrogen sources (at $0.12 \% \mathrm{w} / \mathrm{v}$ ) in order to test for their utilization. Diazotrophy of the culture was determined by growing strain JA4 $48^{\mathrm{T}}$ under a $\mathrm{N}_{2}$ atmosphere. Growth was measured turbidometrically at $660 \mathrm{~nm}$. Fatty acid methyl esters were prepared, separated and identified according to the instructions for the Microbial Identification System (Microbial ID; Agilent 6850) (Sasser, 1990); this procedure was carried out by Royal Life Sciences Pvt Ltd (Secunderabad, India).

Genomic DNA was obtained from 1-2 ml well-grown liquid culture using a Genomic DNA extraction kit (Qiagen). Recombinant Taq polymerase (Bangalore GeNei) was used for PCR. The PCR was primed with primers F-27 (5'-GTTTGATCCTGGCTCAG-3') and R1489 (5'-TACCTTGTTACGACTTCA-3') (positions 11-27 and 1489-1506, respectively, according to the Escherichia coli 16S rRNA numbering system of the International Union of Biochemistry). PCR amplification was done as described previously (Imhoff et al., 1998) and 16S rRNA gene sequences were obtained by cycle sequencing with a SequiTherm sequencing kit (Biozym) and the chain termination reaction (Sanger et al., 1977) using an automated laser fluorescence sequencer (Pharmacia). Sequences were aligned using the CLUSTAL_X program and a neighbour-joining tree was constructed using MEGA 4.0 software using 500 replicates for non-parametric bootstrap analysis (Tamura et al., 2007). Genomic DNA was extracted and purified according to the method of Marmur (1961) and the G+C content of the DNA was determined by HPLC (Mesbah et al., 1989).

Individual cells of strain JA418 ${ }^{\mathrm{T}}$ were rod-shaped (Fig. 1a), $0.6-1.0 \mu \mathrm{m}$ wide and 3-6 $\mu \mathrm{m}$ long. The cells were highly motile with single polar flagella (Fig. 1b) and multiplied by binary fission. Electron photomicrographs of ultrathin sections of the cells revealed a vesicular type of internal membranes (Fig. 1c). Strain JA418 ${ }^{\mathrm{T}}$ grows well photoorganoheterotrophically [anaerobically in light $\left(30 \mu \mathrm{E} \mathrm{m} \mathrm{m}^{-2}\right.$ $\mathrm{s}^{-1}$ ) with pyruvate as carbon source/electron donor]. Strain $\mathrm{JA} 418^{\mathrm{T}}$ was able to grow photolithoautotrophically [anaerobically in the light $\left(30 \mu \mathrm{E} \mathrm{m} \mathrm{m}^{-2} \mathrm{~s}^{-1}\right)$ with $\mathrm{Na}_{2} \mathrm{~S} .9 \mathrm{H}_{2} \mathrm{O}$ $(1.0 \mathrm{mM})$ or $\mathrm{Na}_{2} \mathrm{~S}_{2} \mathrm{O}_{3}(5.0 \mathrm{mM})$ as electron donors with $\mathrm{NaHCO}_{3}(0.1 \% \mathrm{w} / \mathrm{v})$ as carbon source] and photolithoheterotrophically [anaerobically in the light $\left(30 \mu \mathrm{E} \mathrm{m}^{-2} \mathrm{~s}^{-1}\right)$ with $\mathrm{Na}_{2} \mathrm{~S} .9 \mathrm{H}_{2} \mathrm{O}(1.0 \mathrm{mM})$ or $\mathrm{Na}_{2} \mathrm{~S}_{2} \mathrm{O}_{3}(1 \mathrm{mM})$ as electron donors and organic substrates $(0.3 \% \mathrm{w} / \mathrm{v})$ as carbon source]. Chemolithoautotrophy [aerobic growth in the dark with thiosulfate $(5.0 \mathrm{mM})$ as electron donor and $\mathrm{NaHCO}_{3}(0.1 \% \mathrm{w} / \mathrm{v})$ as carbon source], chemo-organoheterotrophy and fermentative growth [anaerobically in the dark with pyruvate as fermentable substrate $(0.3 \% \mathrm{w} / \mathrm{v})$ ] could not be demonstrated. Utilization of substrates as carbon/electron donors under photolithoheterotrophic conditions is detailed in Table 1. Thiosulfate, thioglycolate, elemental sulfur and sodium sulfide (each at $1 \mathrm{mM}$ ) were utilized as sulfur sources under phototrophic conditions.

Ammonium chloride, glutamate, glutamine and urea were utilized as nitrogen sources, while molecular nitrogen, nitrate and nitrite did not support growth. Acetylene reduction activity as a marker for the enzyme nitrogenase was also not observed in strain JA4 $418^{\mathrm{T}}$. Salt was required for growth of strain JA4 $18^{\mathrm{T}}$, and growth occurred in the
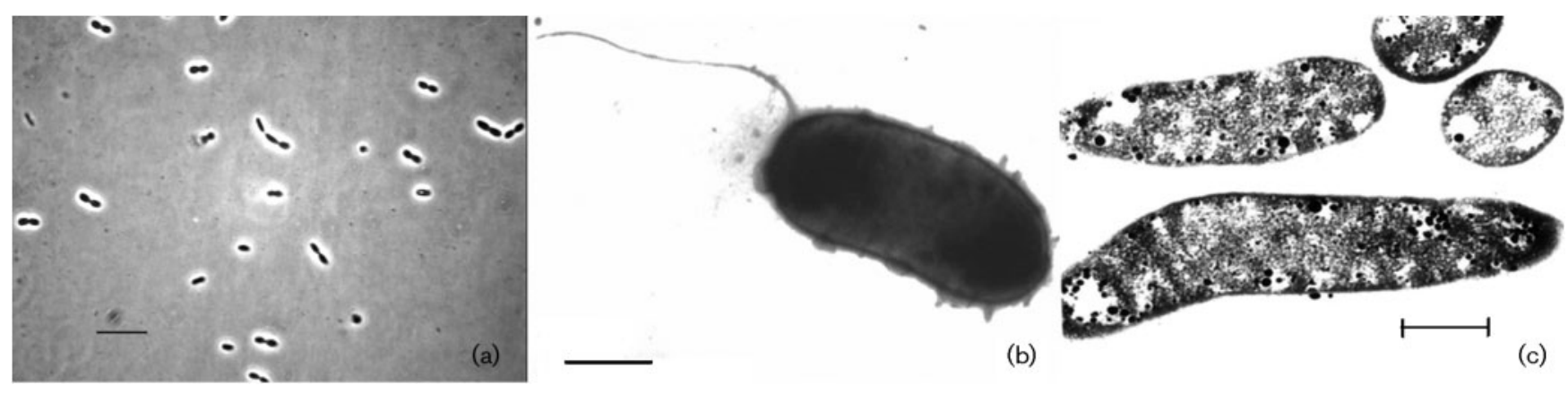

(b)

(c)

Fig. 1. (a) Phase-contrast photomicrograph of cells of strain $J A 418^{\top}$. Bar, $16.6 \mu \mathrm{m}$. (b) Electron photomicrograph showing monopolar flagellum of strain $\mathrm{JA} 418^{\top}$. Bar, $1 \mu \mathrm{m}$. (c) Transmission electron photomicrograph showing vesicular intracytoplasmic membrane structures of strain $\mathrm{JA} 418^{\top}$. Bar, $869 \mathrm{~nm}$. 
Table 1. Differentiating characteristics of type strains of species of the genus Marichromatium

Strains: 1, strain JA418 ${ }^{\mathrm{T}}$; 2, Mch. bheemlicum JA124 ${ }^{\mathrm{T}}$; 3, Mch. indicum JA100 ${ }^{\mathrm{T}}$; 4, Mch. gracile DSM 203 ${ }^{\mathrm{T}}$; 5, Mch. purpuratum DSM 1591 ${ }^{\mathrm{T}}$. Data were obtained in this study. Organic substrate utilization was tested during photolithoheterotrophic growth in the presence of $\mathrm{Na}_{2} \mathrm{~S} .9 \mathrm{H}_{2} \mathrm{O}$ $(1 \mathrm{mM})$. Organic substrate utilization, vitamin requirements and nitrogen source utilization were examined and FAME analysis was carried out for all five strains under identical conditions from cells grown at $\mathrm{pH}$ 7.5. +, Substrate utilized; -, substrate not utilized/fatty acid not detected. DNA $\mathrm{G}+\mathrm{C}$ contents were determined by HPLC. All five strains were positive for utilization of acetate, pyruvate and malate and negative for utilization of glutamate, glucose, tartrate, mannitol and benzoate. All five strains were similar in the presence of rod-shaped cells with single polar flagella and internal membranes of the vesicular type and cell division by binary fission.

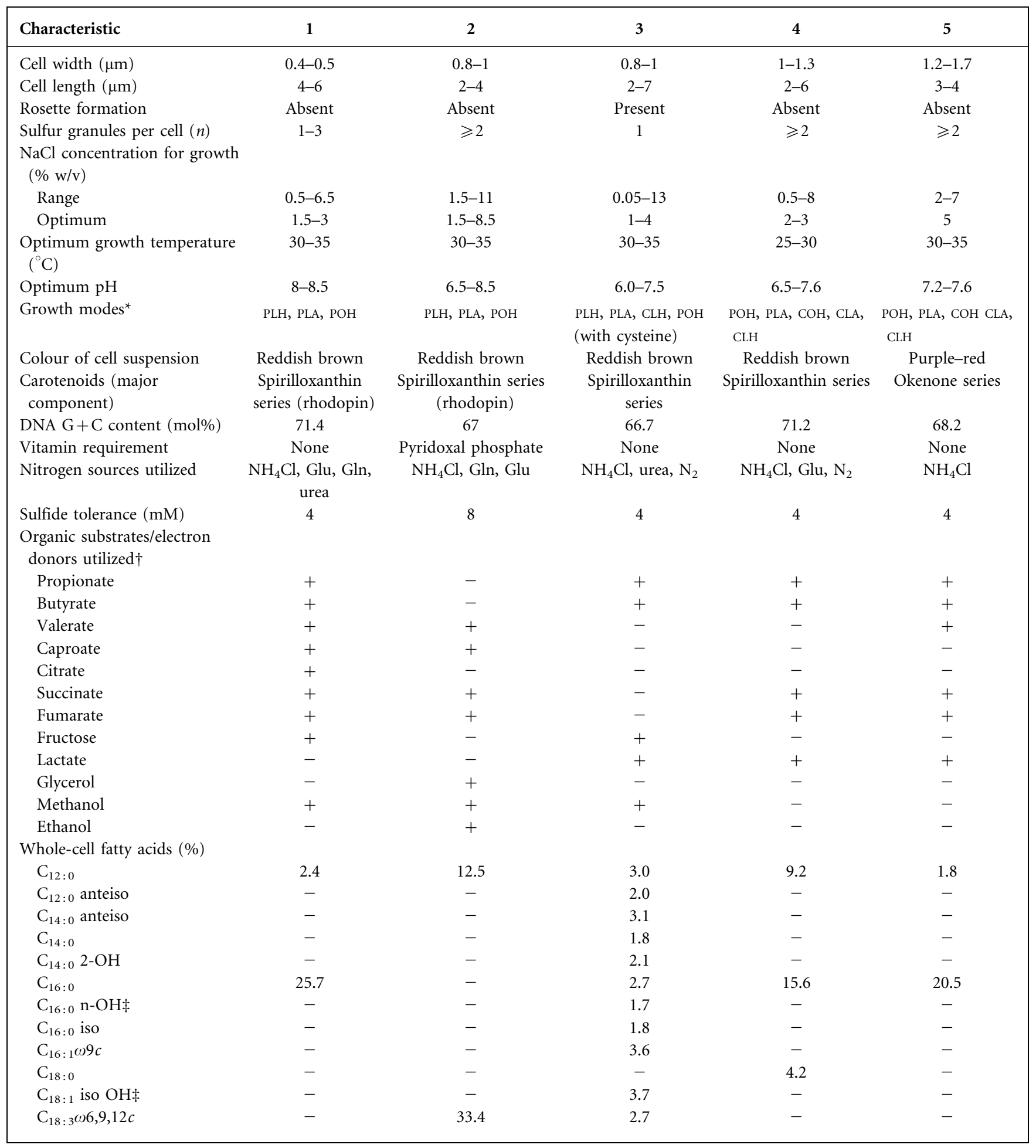


Table 1. cont.

\begin{tabular}{|lccccc|}
\hline Characteristic & $\mathbf{1}$ & $\mathbf{2}$ & $\mathbf{3}$ & $\mathbf{4}$ & $\mathbf{5}$ \\
\hline $\mathrm{C}_{16: 1} \omega 7 c / \mathrm{C}_{16: 1} \omega 6 c$ & 28.4 & - & - & 10.5 & 29.4 \\
$\mathrm{C}_{16: 1} \omega 7 c$ alcohol & - & - & - & 2.1 & - \\
$\mathrm{C}_{18: 1} \omega 7 c$ & 37.0 & - & 68.5 & 49.2 & 40.4 \\
$\mathrm{C}_{18: 1} \omega 5 c$ & 0.3 & 54.0 & & - & - \\
\hline
\end{tabular}

${ }^{*} \mathrm{CLA}$, Chemolithoautotrophy; $\mathrm{CLH}$, chemolithoheterotrophy; $\mathrm{COH}$, chemo-organoheterotrophy; PLA, photolithoautotrophy; PLH, photolithoheterotrophy; $\mathrm{POH}$, photo-organoheterotrophy.

$\dagger$ Results were obtained after three subcultures with the respective substrates and compared against a control without the test substrate.

$\ddagger$ Position of hydroxyl group and/or double bond not identified.

presence of $0.5-6.5 \%(\mathrm{w} / \mathrm{v}) \mathrm{NaCl}$, with optimum growth at $1.5-3.0 \%(\mathrm{w} / \mathrm{v}) \mathrm{NaCl}$ (Supplementary Fig. S1a, available in IJSEM Online). Strain JA418 ${ }^{\mathrm{T}}$ grew at $\mathrm{pH}$ 6.5-10.0 with optimum growth at $\mathrm{pH}$ 8.0-8.5 (Supplementary Fig. S1b) and at $25-30{ }^{\circ} \mathrm{C}$ with optimum growth at $30^{\circ} \mathrm{C}$. Yeast extract was required as a growth factor $(0.03 \% \mathrm{w} / \mathrm{v})$. The predominant cellular fatty acids were $\mathrm{C}_{16: 0}, \mathrm{C}_{16: 1} \omega 7 \mathrm{cl}$ $\mathrm{C}_{16: 1} \omega 6 c$ and $\mathrm{C}_{18: 1} \omega 7 c$.

Photosynthetically grown cultures of strain $\mathrm{JA} 418^{\mathrm{T}}$ were reddish brown. The whole-cell absorption spectrum (Supplementary Fig. S2a) of strain JA $418^{\mathrm{T}}$ showed absorption maxima at $374,488,593,803$ and $857 \mathrm{~nm}$. The peak in the methanolic spectrum at $770 \mathrm{~nm}$ confirmed the presence of bacteriochlorophyll $a$ and the absorption spectrum of pigments extracted with acetone (Supplementary Fig. S2b) gave absorption maxima at 473 and $503 \mathrm{~nm}$, indicating the presence of the spirilloxanthin series of carotenoids. HPLC analysis of the carotenoid indicated that strain $\mathrm{JA} 418^{\mathrm{T}}$ contained rhodopin as the major pigment.

The DNA base composition of strain JA418 ${ }^{\mathrm{T}}$ was $71.4 \mathrm{~mol} \%$ $\mathrm{G}+\mathrm{C}$ (by HPLC). The phylogenetic relationship of strain $J A 418^{\mathrm{T}}$ to other purple sulfur bacteria was examined by $16 \mathrm{~S}$ rRNA gene sequencing. The data obtained revealed that the sequence (1434 bp) of the new isolate was included in the cluster of the genus Marichromatium (Fig. 2), but was distinct from those of other species of the genus. The highest 16S rRNA gene sequence similarities of strain JA418 ${ }^{\mathrm{T}}$ were found with the type strains of Mch. gracile (95.9\%), Mch. indicum (95.6\%), Mch. purpuratum (95.5\%) and Mch. bheemlicum (95.6\%).

In addition to $16 \mathrm{~S}$ rRNA gene sequence dissimilarity, strain $\mathrm{JA} 418^{\mathrm{T}}$ showed clear phenotypic differences from other Marichromatium species (Table 1). Important phenotypic traits that distinguish strain JA $418^{\mathrm{T}}$ from other members of the genus Marichromatium include the requirement for slightly alkaline $\mathrm{pH}(8-8.5)$ for optimal growth and the lack of chemotrophy in strain JA418 ${ }^{\mathrm{T}}$, characters that distinguish it from other Marichromatium species except Mch. bheemlicum. Strain JA4 $48^{\mathrm{T}}$ differs from Mch. bheemlicum in vitamin requirements, fatty acid composition, sulfide tolerance, urea utilization, organic substrate utilization and genomic DNA G + C content (Table 1). These major phenotypic differences, supported by large differences in $16 \mathrm{~S}$ rRNA gene sequences, justify the description of a novel species, Marichromatium fluminis sp. nov., to accommodate strain JA418 ${ }^{\mathrm{T}}$.

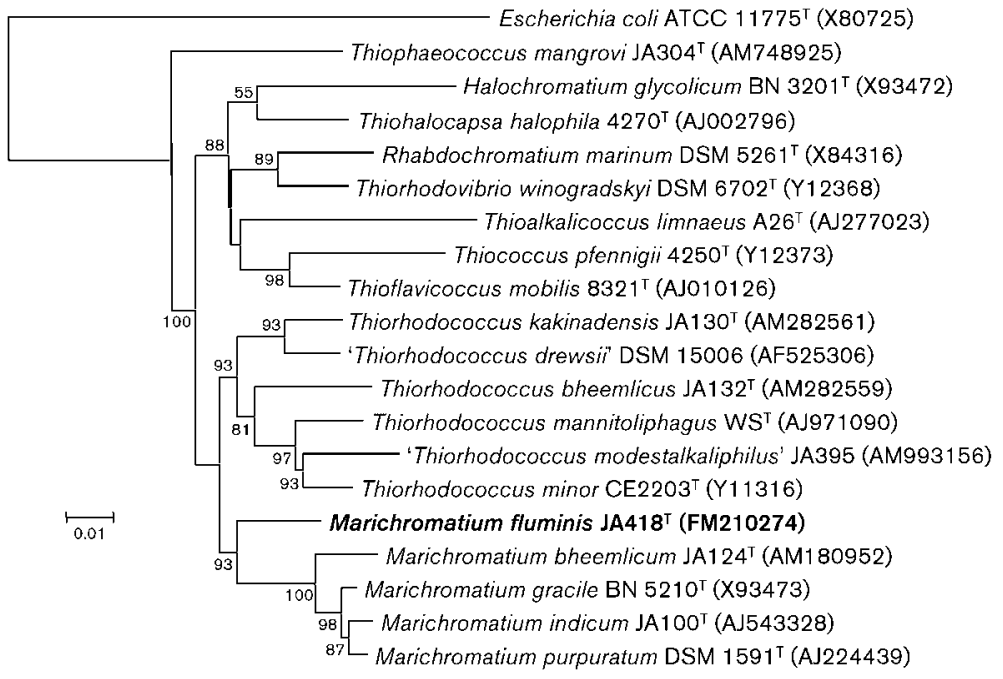

Fig. 2. Neighbour-joining dendrogram depicting the phylogenetic relationships of strain JA418 ${ }^{\top}$ within the family Chromatiaceae determined using the sequence of the 16S rRNA gene; 1350 gap-free sites were compared. Bootstrap percentages from 500 replicates appear next to the corresponding branch. Bar, 1 substitution per 100 nucleotide positions. 


\section{Description of Marichromatium fluminis sp. nov.}

Marichromatium fluminis (flu'mi.nis. L. gen. n. fluminis of a river, referring to the isolation of the type strain from sediment of the Baitarani River, located in Kalibanj forest, Orissa, India).

Cells are rod-shaped, $0.6-1.0 \mu \mathrm{m}$ wide and 3-6 $\mu \mathrm{m}$ long, motile and multiply by binary fission. Gram-negative. Growth occurs under anaerobic conditions in the light (photolithoautotrophy, photolithoheterotrophy and photo-organoheterotrophy). Internal photosynthetic membranes are of the vesicular type. Phototrophic cultures are reddish brown. The in vivo absorption spectrum of intact cells in sucrose exhibits maxima at 374, 488, 593, 803 and $857 \mathrm{~nm}$. Photosynthetic pigments are bacteriochlorophyll $a$ and carotenoids of the spirilloxanthin series (with rhodopin as the major component). Mesophilic (temperature range $20-35{ }^{\circ} \mathrm{C}$ ), exhibits optimum growth at $\mathrm{pH} 8.0-8.5$ and requires $0.5-6.5 \%$ $(\mathrm{w} / \mathrm{v}) \mathrm{NaCl}$ for growth. The major fatty acids are $\mathrm{C}_{16: 0}$, $\mathrm{C}_{16: 1} \omega 7 c / \mathrm{C}_{16: 1} \omega 6 c$ and $\mathrm{C}_{18: 1} \omega 7 c$. Photolithoheterotrophy with $\mathrm{Na}_{2} \mathrm{~S} .9 \mathrm{H}_{2} \mathrm{O}$ and various organic compounds is the preferred mode of growth. Good growth with acetate and pyruvate. Growth also occurs on butyrate and caproate. Thiosulfate, sulfate, sulfite, thioglycolate, cysteine and sodium sulfide are utilized as sulfur sources under phototrophic conditions. Photolithoautotrophic growth occurs. Diazotrophic growth and acetylene reduction activity are absent. The DNA base composition of the type strain is $71.4 \mathrm{~mol} \% \mathrm{G}+\mathrm{C}$ (by HPLC).

The type strain, JA418 ${ }^{\mathrm{T}}\left(=\mathrm{KCTC} 5717^{\mathrm{T}}=\mathrm{NBRC} 105221^{\mathrm{T}}\right)$, was isolated from sediment samples collected from the Baitarani River, located in Kalibanj forest, Orissa, India.

\section{Acknowledgements}

Financial assistance received from the Ministry of Earth Sciences, Government of India, is acknowledged. Use of infrastructure facilities under the DST, FIST Level-II support and UGC (CAS) to HCU is gratefully acknowledged.

\section{References}

Aino, K., Hirota, K., Matsuno, T., Morita, N., Nodasaka, Y., Fujiwara, T., Matsuyama, H., Yoshimune, K. \& Yumoto, I. (2008). Bacillus polygoni sp. nov., a moderately halophilic, non-motile obligate alkaliphile isolated from indigo balls. Int J Syst Evol Microbiol 58, 120-124.

Anil Kumar, P., Sasi Jyothsna, T. S., Srinivas, T. N. R., Sasikala, Ch., Ramana, Ch. V. \& Imhoff, J. F. (2007). Marichromatium bheemlicum sp. nov., a non-diazotrophic, photosynthetic gammaproteobacterium from a marine aquaculture pond. Int J Syst Evol Microbiol 57, 12611265.

Arunasri, K., Sasikala, C., Ramana, C. V., Süling, J. \& Imhoff, J. F. (2005). Marichromatium indicum sp. nov., a novel purple sulfur gammaproteobacterium from mangrove soil of Goa, India. Int J Syst Evol Microbiol 55, 673-679.

Imhoff, J. F. (2005). Family I. Chromatiaceae Bavendamm 1924, $125^{\mathrm{AL}}$ emend. Imhoff 1984b, 339. In Bergey's Manual of Systematic Bacteriology, 2nd edn, vol. 2, part B, pp. 3-9. Edited by D. J. Brenner, N. R. Krieg, J. T. Staley \& G. M. Garrity. New York: Springer.

Imhoff, J. F., Süling, J. \& Petri, R. (1998). Phylogenetic relationships among the Chromatiaceae, their taxonomic reclassification and description of the new genera Allochromatium, Halochromatium, Isochromatium, Marichromatium, Thiococcus, Thiohalocapsa and Thermochromatium. Int J Syst Bacteriol 48, 1129-1143.

Marmur, J. (1961). A procedure for the isolation of deoxyribonucleic acid from microorganisms. J Mol Biol 3, 208-218.

Mesbah, M., Premachandran, U. \& Whitman, W. B. (1989). Precise measurement of the $\mathrm{G}+\mathrm{C}$ content of deoxyribonucleic acid by highperformance liquid chromatography. Int J Syst Bacteriol 39, 159-167.

Pfennig, N. \& Trüper, H. G. (1992). The family Chromatiaceae. In The Prokaryotes. A Handbook on the Biology of Bacteria. Ecophysiology, Isolation, Identification, Applications, 2nd edn, pp. 3200-3221. Edited by A. Balows, H. G. Trüper, M. Dworkin, W. Harder \& K. H. Schleifer. Berlin, Heidelberg \& New York: Springer.

Sanger, F., Nicklen, S. \& Coulson, A. R. (1977). DNA sequencing with chain terminating inhibitors. Proc Natl Acad Sci U S A 74, 54635467.

Sasser, M. (1990). Identification of bacteria by gas chromatography of cellular fatty acids, MIDI Technical Note 101. Newark, DE: MIDI Inc.

Serrano, W., Amann, R. \& Fischer, U. (2009). A new moderately thermophilic and high sulfide tolerant biotype of Marichromatium gracile, isolated from tidal sediments of German Wadden Sea: Marichromatium gracile biotype thermosulfidiphilum. Syst Appl Microbiol 32, 1-7.

Takaichi, S. \& Shimada, K. (1992). Characterization of carotenoids in photosynthetic bacteria. Methods Enzymol 213, 374-385.

Tamura, K., Dudley, J., Nei, M. \& Kumar, S. (2007). MEGA4: molecular evolutionary genetics analysis (MEGA) software version 4.0. Mol Biol Evol 24, 1596-1599. 